\title{
Sebastian Wojciechowski, Terroryzm na początku XXI wieku. Pojęcie, istota $i$ przyczyny zjawiska, Oficyna Wydawnicza Branta, Byd- goszcz-Poznań 2011, ss. 302.
}

Zjawisko terroryzmu istnieje od czasów starożytnych. Terroryzmem posługiwali się Rzymianie, używano go podczas podbojów kolonialnych, Wiosny Ludów, rewolucji francuskiej i rosyjskiej, a także podczas obu wojen światowych. Eskalacja zjawiska na skalę międzynarodową, globalną przypadła na czasy współczesne, tj. początek XXI wieku. Punktem kulminacyjnym były zamachy islamskich ekstremistów w amerykańskich aglomeracjach - Nowym Jorku i Waszyngtonie 11 września 2001 r.

W nielicznych opracowaniach na temat terroryzmu traktowano zbyt wąsko problematykę badawczą wyjaśniającą terminologię związaną z terroryzmem, z uwagi na trudności w jej scharakteryzowaniu oraz usystematyzowaniu. Opracowania miały charakter publicystyczno-faktograficzny lub dotyczyły wybranych elementów zagadnienia, takich jak analiza konkretnych przypadków czy funkcjonowanie organizacji terrorystycznych. Po 11 września 2001 r. zaczęło się pojawiać wiele prac traktujących o terroryzmie, jednak w dalszym ciagu brakowało kompleksowych opracowań, w których ukazano by problematykę związaną z terminologią pojęciową, zawierających istotę oraz cechy, a także interpretujących zjawisko w ramach systemu i oddziałujących na siebie wzajemnie czynników oraz zmiennych. W wielu publikacjach powielano schematy zawarte w innych pozycjach, w dalszym ciagu skupiając się na jednotorowym podejściu do problematyki.

Zbadaniem i opisaniem zjawiska terroryzmu, aspektów teoretycznych, wieloaspektowości i interferencyjności w sposób systemowy zajął się polski naukowiec, pracownik Uniwersytetu im. Adama Mickiewicza w Poznaniu oraz Instytutu Zachodniego w Poznaniu - Sebastian Wojciechowski w pracy Terroryzm na poczqtku XXI wieku. Pojęcie, istota i przyczyny zjawiska. W kompleksowy sposób przedstawia rozważania na temat koncepcji teoretycznych, w precyzyjny i przejrzysty sposób prezentuje zawarte koncepcje, używając problematyczno-chronologicznych ram dysertacji. Recenzowana książka jest zbiorem starannie opracowanych zagadnień związanych z pojęciem, istotą i przyczyną terroryzmu oraz interferencyjnością zjawiska. W głównym kontekście cezura czasowa opracowania obejmuje XXI wiek, jednak dokonując analizy poszczególnych zagadnień, jak geneza zjawiska, Autor przyjmuje wcześniejsze ramy czasowe.

Praca składa się ze wstępu, części pierwszej dotyczącej zakresu i charakteru współczesnego terroryzmu, części drugiej, w której skupiono się na analizie przyczyn zjawiska i z podsumowania - próby syntezy interferencyjności terroryzmu, która jest przykładem nowatorskiej metodologii badań przyczyn zjawiska terroryzmu, opracowanej przez Autora. Wykorzystane metody badawcze obejmują: analizę i syntezę, abstrahowanie oraz indukcję i dedukcję, a także behawioralną metodę wyjaśnienia zagadnienia oraz systemowe podejście do całości problemu. Zastosowana została konstrukcja problematyczno-chronologiczna. Monografia opiera się na dogłębnym zbadaniu elementów składowych zjawiska, ich wzajemnych korelacji oraz interferencji, a także sfery przyczynowo-skutkowej.

W części pierwszej rozpatrzono genezę oraz eskalację terroryzmu, opisano poszczególne etapy kształtowania zjawiska, elementy składowe, cechy i mechanizmy. Nie powielono przy tym jednej, starej koncepcji, tylko przedstawiono wiele różnych opisów. Terroryzm ukazano jako system różnorakich czynników wpływających na przyczyny jego zaistnienia, korelacje bodźców oraz mechanizmów powiązanych ze zjawiskiem, a także skutków, które 
mogą powodować dalszą eskalację problemu lub jego zmniejszenie. Jest to siatka oddziaływania różnych elementów i mechanizmów wzajemnie na siebie wpływających, oddziałujących i uzupełniających się nawzajem. Zauważając, że usystematyzowana wiedza oraz nauka o terroryzmie mogą skuteczniej pomóc w zwalczaniu problemu, w opracowaniu wskazano i zanalizowano elementy składowe oraz funkcje dezintegrujące i integrujące terroryzmu, a także rozpatrzono to zjawisko na tle innych zjawisk dezintegrujących (takich jak separatyzm czy fundamentalizm), a także w kontekście ideologii (politycznych, ekonomicznych, etnicznych, religijnych) i uwarunkowań społecznych. Zwrócono uwagę na ewolucję terroryzmu i umiejętność jego dostosowywania się do zmieniających się realiów, w szczególności globalizacji. Ukazano genezę zjawiska, a także interakcje zachodzące między elementami składowymi (przyczynowo-skutkowe, czasowe i przedmiotowe). Autor zbadał problematykę wykorzystując koncepcję triady terrorystycznej, w której zawierają się trzy główne typy determinantów: sferę idei, źródła ekonomiczno-społeczne oraz przyczyny psychologiczne.

W pracy wyjaśniono problematykę związaną z trudnościami z usystematyzowaniem pojęciowym oraz teoretycznym zjawiska. Choć kwestia ta pojawia się w wielu opracowaniach, Autor nie powiela po raz kolejny schematów opisujących to zjawisko, a w nowatorski sposób ukazuje je, prezentując spójnie i przejrzyście przytoczone kwestie. Optymalnie dobrano sposób opisywania wszelakich aspektów związanych z terroryzmem, poczynając od sfery terminologicznej. Na tym polu wskazano zmiany pojmowania terminów „terror" i „terroryzm”, odniesiono się również do pojęć pokrewnych, takich jak „,przemoc”, ,działalność przestępcza”, „przemoc kryminalna”, „czystki etniczne”, „wojna”, „powstanie”. Zaprezentowano różne sposoby definiowania terroryzmu, przejawiające się w pracach Ligi Narodów, ONZ i Komitetu ds. Międzynarodowego Terroryzmu (KDMT), Rady Bezpieczeństwa ONZ, Międzynarodowego Trybunału Sprawiedliwości, Rady Gospodarczo-Społecznej, a także innych organizacji międzynarodowych (m.in. ICAO, IMO, OPA, LPA, NATO, Rada Europy, UE). Pojęcie terroryzm zostało przedstawione w świetle regulacji prawnych różnych państw, a także w oparciu o definicje słownikowe czy koncepcje autorskie teoretyków terroryzmu. Tę część pracy skonkludowano stwierdzając, iż jest to pojęcie zbyt obszerne, aby jednoznacznie je określić i sformułować. Jednocześnie jednak Autor wskazał na potrzebę stworzenia uniwersalnej definicji terroryzmu, aby móc uruchomić efektywne mechanizmy oraz strategie zapobiegania zjawisku, a także z powodów formalnoprawnych. Podsumowanie stanowi autorska definicja terroryzmu. W celu uporządkowania i wskazania „fundamentu” terroryzmu, przedstawiono pięć kluczowych pytań: kto, jak, dlaczego, kto/co był/było celem, kogo lub czego przejaw terroryzmu dotyczył; z jakim skutkiem? Powyższych pięć pytań potraktowano jako istotę zjawiska, prezentując w dalszej części cechy terroryzmu i dokonując jego typologii. W celu dogłębnego zbadania zjawiska, zaprezentowano interferencyjną koncepcję współczesnego terroryzmu, zakładającą m.in. rozpatrywanie owego zjawiska przy uwzględnieniu: elementów składowych i ich interakcji, wpływających na nie czynników i analizowanego obszaru. Wskazać należy, że zaproponowana przez S. Wojciechowskiego metoda ma charakter uniwersalny i posłużyć może do analizy i prognozy terroryzmu, ale również innych podobnych zjawisk, jak separatyzm, fundamentalizm czy nacjonalizm.

We wprowadzeniu do części drugiej, zwrócono uwagę na złożoność problemu oraz na niepełne i niedoskonałe opracowania nad studiami związane z problematyka, w których wybiórczo bazuje się z reguły na głównych przesłankach, podchodząc do tematu w sposób 
emocjonalny, a w konsekwencji subiektywny. Zwracając uwagę, że istnieje grupa wielu czynników determinujących zjawisko, S. Wojciechowski zaproponował analizę uwzględniającą uwarunkowania terytorialno-etniczne, religijno-kulturowe, ekonomiczno-społeczne, a także historyczno-polityczne, psychologiczne oraz inne, do których zaliczono np. działania liderów politycznych, zwiększające się migracje i napływ ludności odmiennej kulturowo, rolę mediów ${ }^{1}$. Wykorzystując interferencyjny model przyczyn terroryzmu (opierający się na założeniu przenikania, interakcji wielu czynników jako systemu - całej siatki powiązań) wskazano na tzw. triadę terrorystycznej motywacji, ujmując trzy grupy przyczyn terroryzmu: terroryzm powodowany ideologiami (sfera serca), uwarunkowaniami ekonomiczno-społecznymi (sfera ciała) i aspektami psychicznymi (sfera umysłu). Interferencyjny model terroryzmu i wynikająca z niego koncepcja triady terrorystycznej scharakteryzowane zostały jako jeden ze sposobów rozpatrywania terroryzmu, oraz jako autorska próba usystematyzowania przyczyn zjawiska.

W podsumowaniu opracowania S. Wojciechowski podjął próbę syntezy interferencyjności terroryzmu. Zwrócił uwagę na kluczowe kwestie jej dotyczące, m.in.: rozróżnienie terroryzmu lokalnego od globalnego, korelację przyczyn oraz skutków, asymetryczny i sieciowy charakter terroryzmu oraz jego ewolucję, globalizację, media, wybór taktyki i strategii, rozwój technologiczny, motywy. W ramach tej koncepcji Autor ponownie wskazał na dezintegrujące, ale i integrujące funkcje terroryzmu, a także na korelacje z otoczeniem, które określone zostało jako otoczenie systemu terrorystycznego. Uwzględnił również interferencję tych procesów z działaniami poszerzania zasięgu działania organizacji terrorystycznych i tworzenia ponadnarodowych struktur. Częścią koncepcji interferencyjnej jest także mechanizm kształtowania się terroryzmu, który cechuje się dynamiką i złożonością, a determinowany jest przez czynniki zewnętrzne i wewnętrzne. Istotnym podmiotem terroryzmu jest organizacja terrorystyczna, która wchodzi w interakcje z otoczeniem i jest determinowana czynnikami zewnętrznymi i wewnętrznymi, stanowiąc w ten sposób kolejny aspekt interferencyjności.

Zjawisko terroryzmu oddziałuje na wiele procesów i mechanizmów społecznych od jednostek po działalność międzynarodową, wpływa na dezintegrację i destabilizację, będąc przyczyna, jak i skutkiem tych procesów. Aby móc przeciwdziałać zagrożeniu zaprezentowano koncepcję kontr-antyterroryzmu, składającego się z podstawowych elementów takich jak zapobieganie, zwalczanie, ochrona, reagowanie czy prognozowanie tego zjawiska. Realizacja wyżej przedstawionych elementów jest trudnym do osiagnięcia zadaniem z powodu złożoności problemu. Pomóc może pełniejsze poznanie przyczyn zjawiska, jego istoty oraz specyfiki, w czym pomaga omówiona lektura i przedstawiona w niej interferencyjna koncepcja terroryzmu.

W ogólnej refleksji nad książką, należy podkreślić, że autorski, nowatorski sposób usystematyzowania przyczyn terroryzmu, szerokie podejście do problemu interferencyjności i wynikająca z niego koncepcja triady terrorystycznej zasługują na bardzo wysoką ocenę. Jako innowacyjny sposób badawczy, posłużyć może do dalszych badań nad problematyką

1 Autor przybliżył również inne sposoby klasyfikacji przyczyn terroryzmu, jak: powody proste i złożone; uwarunkowania historyczne, społeczne, polityczne i kulturowe oraz bezpośrednie, czyli motywacje, czynniki grupowe, ideologiczne i organizacyjne. Inny typ klasyfikacji przyczyn opiera się na podziale na cztery kategorie: przyczyny strukturalne, tzw. przyśpieszacze, przyczyny motywacyjne, zapalniki-detonatory. Przedstawione zostały ponadto inne klasyfikacje przyczyn oparte na badaniach m.in. A. Marsella, T. Bjørgo, A. Cronina. 
procesów dezintegrujących, przede wszystkim terroryzmu, ale i innych zjawisk, jak nacjonalizm, separatyzm czy fundamentalizm. Wysoka ocena recenzowanej książki podyktowana jest również odwołaniami Autora do dorobku naukowego wielu naukowców z całego świata, którymi przesycone jest opracowanie. Sebastian Wojciechowski w umiejętny sposób połączył dostępne materiały naukowe z własną wiedzą i doświadczeniem, tworząc nowy wkład w dziedzinie badań nad terroryzmem. Wzbogaca on wiedzę o najnowszą metodologię badawcza, zapewniając kontakt z nowatorskimi osiągnięciami naukowymi.

Wojciech STANKIEWICZ

Uniwersytet Warmińsko-Mazurski, Olsztyn

\section{Анатолий А. Вассерман, Россия, включая Украину. Единство или гибель, Русь-Олимп, Астрель 2010, ss. 448.}

Rosjanie przez stulecia żyli w przeświadczeniu, że Ukraina jest częścią Rosji, a jej kultura oraz język świadczą jedynie o bogactwie tego samego dziedzictwa ${ }^{1}$. W Związku Socjalistycznych Republik Radzieckich, w nauce i środkach masowego przekazu funkcjonował powszechny mit o Rusi Kijowskiej, jako kolebce trzech „bratnich narodów” (Rosjan, Ukraińców i Białorusinów), jak również mit o Rosji - „Starszym Bracie” obu pozostałych (tendencja do takiego postrzegania historii jest nadal widoczna w Federacji Rosyjskiej). Mity te umacniane były doktrynami geopolitycznymi o Moskwie, jako „Trzecim Rzymie” i o rzekomym posłannictwie danym Rosjanom przez Boga w świecie słowiańskim. Ta doktryna słowianofilska, którą odrzucają Słowianie Zachodni i Południowi, nieuznający „,prawa” Rosji do „opieki” nad nimi, jest nadal w zmodyfikowanych formach kierowana do Ukraińców i Białorusinów². Proklamowanie niepodległego państwa ukraińskiego wywołało zamieszanie w Rosji nie tylko z powodów sentymentalnych - rozmaite koła polityczne obawiały się destrukcyjnego wpływu utraty Ukrainy dla gospodarki rosyjskiej, a także stworzenia przez nią w przyszłości centrum opozycji antyrosyjskiej w sojuszu z innymi państwami Europy Środkowej i Wschodniej ${ }^{3}$. Pojawienie się Ukrainy jako realnego i wykazującego istotne cechy trwałości czynnika geopolitycznego zmusiło Rosję (bardziej niż rozpad ZSRR i bardziej niż rozszerzanie NATO na kraje Europy Środkowo-Wschodniej) do poważnego przeformułowania swojej koncepcji interesów narodowych, do modyfikacji doktryny militarnej i przeorientowania priorytetów polityki zagranicznej ${ }^{4}$. Początkowo rządy rosyjskie nie miały jakiejkolwiek koncepcji polityki wobec Ukrainy. Późniejsze lata

1 Zob.: G. Simon, Rosja-restauracja imperium czy poczatek europejskiego państwa narodowego?, „Przegląd Zachodni” 1994, nr 2, s. 93. Zob. także: Ł. Donaj, Polityka bezpieczeństwa niepodległej Ukrainy 1991-2004, Łódź 2005, s. 53-59.

2 Zob.: S. Trochimczuk, Geopolityczna rola i miejsce Ukrainy w Europie w kontekście partnerstwa polsko-ukraińskiego, w: Polska i jej sqsiedzi wobec przemian cywilizacyjnych i geopolitycznych, Biuletyn „Geopolitical Studies”, z. 4, red. M. Jakubowski, Warszawa 1998, s. 141; B. Cywiński, Przyszłość Europy Wschodniej, „Rzeczpospolita”, 12-13.12.1992; oraz: B. Osadczuk, Horpyna nie chce za maż. Ukraina: Po co straszyć upiorami?, „Polityka” nr 9, 28.02.1998.

3 S. Bieleń, Ukraina a Rosja-niezależność i dominacja, „Polityka Wschodnia” 1998, nr 1, s. 12.

4 J. Kozakiewicz, Rosja w polityce niepodległej Ukrainy, Warszawa 1999, s. 19. Zob. także: B. Łomiński, Polityka poradzieckiej Rosji wobec Europy Środkowej, „Polityka Wschodnia” 1997, nr 2. 